\title{
Nursing Care Systematization in a basic health unit: perception of the nursing team*
}

\author{
Sistematização da Assistência de Enfermagem em unidade básica \\ de saúde: percepção da equipe de enfermagem \\ Sistematización de la Asistencia de Enfermería en unidad básica \\ de salud: percepción del equipo enfermero
}

Grasielle Camisão Ribeiro' ${ }^{1}$, Maria Clara Padoveze ${ }^{2}$

How to cite this article:

Ribeiro GC, Padoveze MC. Nursing Care Systematization in a basic health unit: perception of the nursing team. Rev Esc Enferm USP. 2018;52:e03375. DOI: http://dx.doi.org/10.1590/S1980-220X2017028803375

\footnotetext{
* Extracted from the dissertation "Diagnóstico situacional da Sistematização da Assistência de Enfermagem de uma unidade básica de saúde de Campinas - SP”, Programa de Pósgraduação em Enfermagem em Atenção Primária no Sistema Único de Saúde, Escola de Enfermagem de São Paulo, 2015.

1 Universidade de São Paulo, Escola de Enfermagem, Programa de Pósgraduação em Enfermagem em Atenção Primária, São Paulo, SP, Brazil.

2 Universidade de São Paulo, Escola de Enfermagem, Departamento de Enfermagem em Saúde Coletiva, São Paulo, SP, Brazil.
}

\begin{abstract}
Objective: To conduct a situational diagnosis of the Nursing Care Systematization (NCS) in a Basic Health Unit from the perception of the nursing team. Method: This was a quantitative, descriptive-exploratory study, conducted in a Basic Health Unit in the interior of São Paulo state, Brazil. A structured questionnaire containing Likert scale was used for data collection, previously validated by specialists. Results: The questionnaire was applied to 21 nursing professionals. It was verified that implementation of NCS and the nursing process is still incipient in the Basic Health Units. Regarding its use in all nursing actions: $19 \%$ of respondents believe that it is never used, $38 \%$ thought that it is rarely implemented, and $29 \%$ responded sometimes. The main difficulties identified were related to the lack of institutional structure, highlighting a lack of capacity by the institution (81\%). The team has a reasonable understanding about the subject, but pointed out that professional education does not prepare them for performing NCS in primary care. Conclusion: Institutional interest in NCS is necessary to enable implementation. The study can contribute to the effective implementation in this unit and point out guidelines for its implementation in other similar contexts.
\end{abstract}

DESCRIPTORS

Primary Care Nursing; Nursing Process, Nursing, Team; Nursing Assessment. 


\section{INTRODUCTION}

Nursing Care Systematization (NCS) is a care management tool that provides subsidies for organizing nursing care, with the Nursing Process (NP) being one of its main pillars ${ }^{(1)}$. The NCS enables organizing professional work regarding method, personnel and instruments, making the NP operational ${ }^{(2)}$. In turn, the Nursing Process is "a nurse's intellectual work tool that guides the clinical reasoning process and diagnostic decision-making, results and interventions"(3).

Implementing NCS is not only an option for organizing nursing work, it is a legal determination for nursing, as established by Resolution COFEN 358/2009, which states that: "The NP must be carried out in a deliberate and systematic manner, in all environments, public or private, in which professional nursing care occurs"(2).

However, there are difficulties for implementing NCS in professional practice, especially in primary care. Although implementation of NCS and the NP is a legal determination, it has not yet occurred satisfactorily ${ }^{(4)}$.

In primary care, NCS implementation still seems to be very incipient. One of the factors that may be related to this situation is poor training, since primary care nurses refer to having weak knowledge about $\mathrm{NCS}^{(5)}$.

During the literature review, we identified a shortage of articles on NCS or NP in primary health care, and the reported experiences were predominantly in the hospital setting. This converges with a study that analyzed dissertations and theses addressing NCS/NP in primary care, which found that only $5.0 \%$ from a sample of 120 dissertations and theses covering aspects about NCS and NP were related to primary care ${ }^{(6)}$.

Among the few reports of NCS experience in primary care, reports from Curitiba stand out. In partnership with the Brazilian Association of Nursing (ABEn-Associação Brasileira de Enfermagem), an implementation process was initiated to use the nursing vocabulary known as the International Classification of Nursing Practices in Collective Health $\left(C I P E S C^{\circ}\right)$, which proposes a nursing classification compatible with the conceptual bases of the SUS (Unified Heath System, in Portuguese Sistema Único de Saúde, SUS). This vocabulary was included in the computerized system of basic health units, including the diagnoses and nursing interventions elaborated by the work group. It was verified that it is possible to apply a classification system adapted to the local reality, increasing the visibility of nursing actions ${ }^{(7)}$.

NCS establishment is a complex and laborious process. One study sought to identify some steps to subsidize its implementation. First, recognition of the institutional reality was necessary. Other steps identified were: team awareness; definition of the theoretical reference; preparation of instruments for implementing the NP; and practical preparation for NCS implementation ${ }^{(8)}$.

Resolution COFEN 358/2009 considers the terms nursing consultation and nursing process as synonymous. However, this same regulation indicates that "the Nursing Technician and the Nursing Assistant (...) participate in executing the Nursing Process, in whatever capacity, under the supervision and guidance of the Nurse" ${ }^{(2)}$. Therefore, it is important that the whole team understands the concepts of NCS and NP and participate in its accomplishment according to the level of their professional competence.

Considering the potential of the NCS and the need to know the institutional reality, we sought to evaluate how NCS is being performed in primary care in a city in the countryside of São Paulo, having a basic health unit as reference. In order to make the study viable, we choose to perform a clipping of this diagnosis from the perspective of nursing workers.

Thus, the objective of this study was to perform a situational diagnosis of Nursing Care Systematization (NCS) in a Basic Health Unit (BHU) from the nursing team's perception.

\section{METHOD}

\section{Study DESIGN}

This is a descriptive-exploratory study employing a quantitative approach.

\section{StUd LOCATION AND PARTICIPANTS}

The study was conducted in a basic health unit (BHU) in June 2015, in a city in the interior of São Paulo (Campinas), which has a population under care of 22,643 inhabitants and three reference teams. The study subjects were 27 professionals, members of the BHU nursing team at the time of the study. Since one of the researchers is part of the team, the defined eligible population was 26 professionals after applying the exclusion criterion. The final sample consisted of 21 professionals who were available in the activity period (not on vacation or leave) during data collection and who agreed to participate in the study.

\section{Data collection}

The nursing professionals were personally approached by the researcher, who explained the study and invited them to freely participate, being informed about the ethical aspects of the research. In cases of acceptance and after reading and signing the clear and Informed Consent Form, the questionnaire was presented to them, which was then filled out and returned by the interviewee.

The applied questionnaire was structured and previously validated by specialists. The validation procedure was carried out in a previous step by means of a content validation technique with seven specialists, with 0.8 being considered as the cut-off Content Validation Index (CVI) to approve the questionnaire items. Relevant adjustments were made in the text when indicated by the specialists, and the elements that achieved the required CVI were maintained.

The questionnaire consists of seven domains and 66 questions, and was organized in three parts: 1) Participant characterization; 2) Individual perception of NCS/NP in the aspects of knowledge, difficulties, benefits and facilitators; and 3) Individual perception of the situation of NCS and NP in the participant's work unit. 
A Likert-type scale was used in the second and third part of the questionnaire, in which the respondent evaluated the statements expressing their point of view on a certain statement, marking an option on a scale of values from 1 to 5 according to their degree of agreement. In the second part of the questionnaire, the response options were: 1 - I totally disagree; 2 - I disagree; 3 - I am in doubt; 4 - I agree; and 5 - I totally agree. In the third part, the response options were: 1 - Never; 2 - Rarely; 3 - Sometimes; 4 - Often; and 5 - Always.

\section{Data analysis}

The questions were analyzed quantitatively. A database was constructed and analyzed using Microsoft Excel ${ }^{\infty}$ 2007. Data were presented by means of absolute and relative frequency distribution of responses related to the studied variables.

\section{EthicAl PROCEDURES}

In compliance with Resolution 466/2012/CONEP, the project was submitted to the Ethics Committee of the Nursing School of the Universidade de São Paulo in 2015, under Opinion number 1.075.023. The project was also approved by the partner institution where the research was carried out.

\section{RESULTS}

\section{PARTICIPANTS' CHARACTERIZATION}

Twenty-one (21) nursing professionals took part in the study, with the vast majority (95\%) being female. Their age ranged from 24 to 67 years. Regarding the professional category, 71\% worked as nursing assistants, 19\% as nurses and $10 \%$ as nursing technicians. The majority $(62 \%)$ of the team had worked for more than 10 years in the institution. It was verified that the average years since graduation was 14 years.

\section{Perception of the nursing team on the Nursing Care Systematization (NCS) and Nursing Process (NP)}

In this domain, we sought to analyze the concept that the nursing team had regarding NCS and NP, considering that the team's understanding of the subject is paramount for implementing NCS. Among the 10 conceptual issues proposed, the team agreed on six. In addition, a significant number of respondents chose the option "I am in doubt" about questions 1 to 6 .

The team partially or totally agreed with some of the favorable aspects of the NCS from a managerial point of view, such as: "The NCS helps in planning and organizing care" (71.4\%) and "NCS helps make nursing practice visible" (81\%). Regarding NP, the majority of the nursing team totally or partially agreed on its composition in five stages: nursing data collection, nursing diagnosis, nursing planning, implementation and evaluation (57.1\%), and also with regard to its objective to describe the nursing care provided in a standardized way (71.4\%). In addition, the team understood that Nursing Diagnostics and Prescription (85.7\%) were privately assigned to nurses. It is worth noting that most of the team agreed that "One of the reasons that hinder the development of nursing as a science is the lack of a universal standardized language for recording their actions" (67\%).

\section{Perception of the nursing team on NCS and NP TRAINING}

All the participating nurses affirmed that their academic training did not prepare them to perform NCS in the context of primary care. However, in the perception of the assistants and technicians interviewed, there was no convergence of opinion: $53 \%$ of the interviewees felt that the courses for technicians and auxiliary staff did not include NCS and NP during professional education, 29\% said they had doubts if this subject had been approached, and 24\% stated that the courses for technicians and assistants do teach the NCS and the NP.

Just over half of the nursing professionals (53\%) considered that they had sufficient knowledge to perform the NCS and the NP in primary care. According to most of the interviewees $(71 \%)$, permanent education facilitates NCS implantation and the vast majority of those interviewed (81\%) agreed that they needed training to implant NCS and to carry out NP in practice.

\section{Perception of the nursing team about the benefits THAT NCS AND THE NP CAN PROMOTE}

The majority of the team agreed (agreement percentage $>85 \%$ ) that the NCS and NP can promote several benefits to the team and to patients: increase the quality of nursing consultations; favor documentation of the nurses' work and their clinical reasoning; increase the autonomy of nurses in their work process; individualize patient care; and enable organization of the team work process.

\section{Perception about the difficulties of implementing NCS AND PERFORMING THE NP IN THEIR UNIT}

In this domain, we sought to identify the barriers for NCS to be established and to perform the NP in the unit. It was verified (Figure 1) that the commonly identified barriers were related to lack of training and demand for excessive work, with interruptions in nursing consultations. However, motivational aspects such as devaluation of nursing professionals by the population were also frequently pointed out by the participants.

\section{Perception of the team on what could facilitate IMPLEMENTATION OF NCS AND PERFORMANCE OF THE NP IN THE UNIT}

Figure 2 shows the perception of the nursing team regarding factors that could enable establishing NCS and NP performance in the unit. There was great agreement regarding the issues of training and knowledge, as well as for adopting protocols. 
Lack of training by the institution

Pressure from demand, too many patients Interruptions during nursing consultations

Devalued by the general population

Lack of adequate structure in the institution

An undefined role of the nurse

Lack of clinics

Devalued by professionals

Non-existence of a printed guide book

Little familiarity with nomenclature

Low complexity of the patients

Nurses do not try to improve themselves

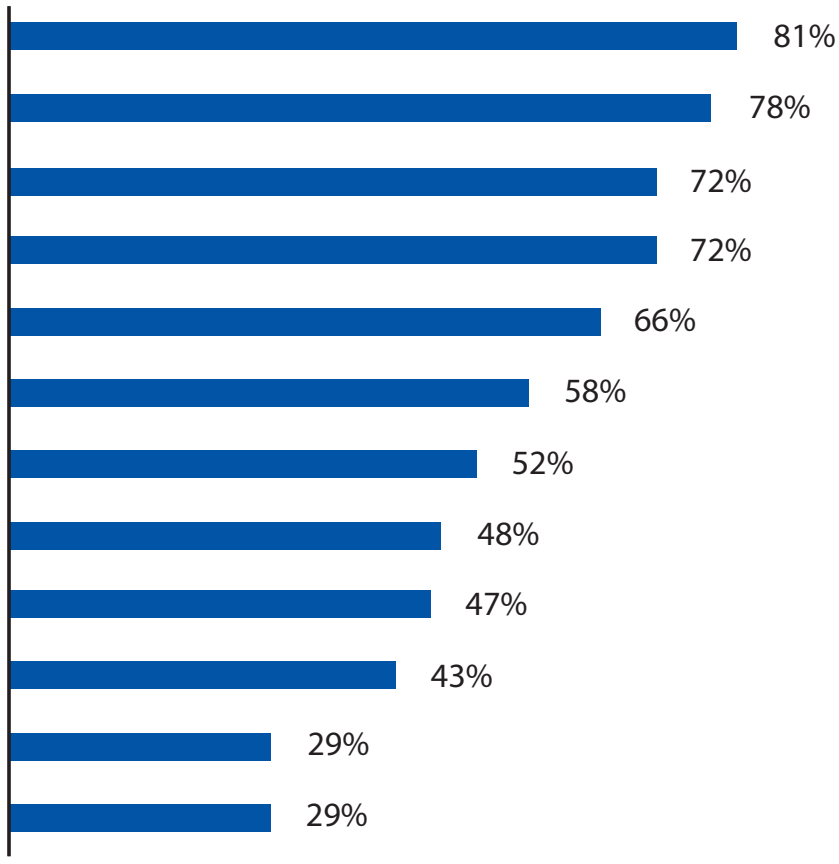

\section{Agreement percentage}

Note: $\mathrm{N}=21$

Figure 1 - Agreement percentage (answers totally agree and partially agree) of the nursing team regarding the barriers for implementing Nursing Care Systematization and the Nursing Process - Campinas, SP, Brazil, 2015.

Offer training to the team Nurse's knowledge /regarding SNC and NP Adoption of protocols Standardized form for systematization Adoption of a standardize nomenclature Nurse's involment with the work Adequate human resources Continuing education for the nurses Existence of electronic medical records

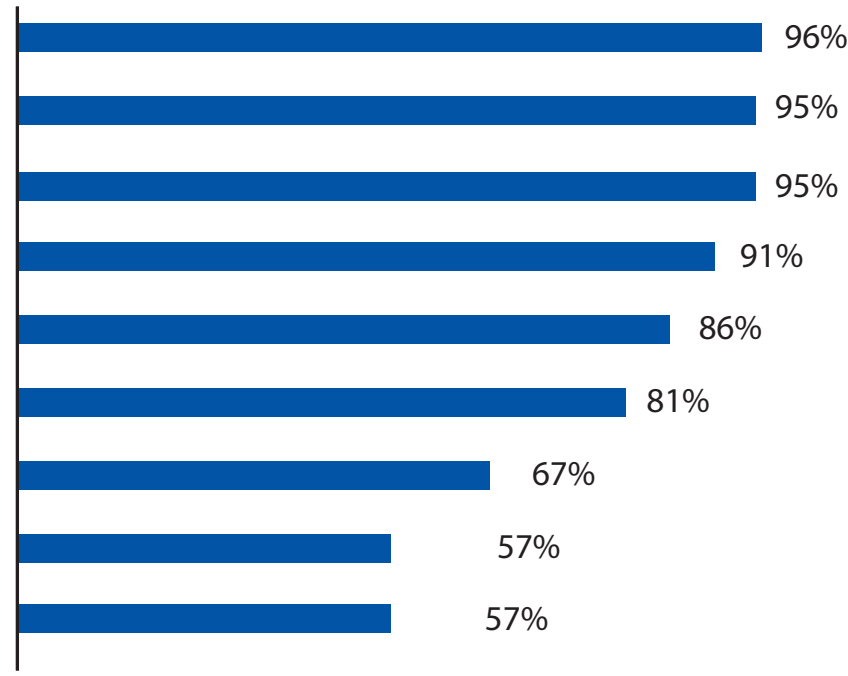

\section{Agreement percentage}

Note: $\mathrm{N}=21$

Figure 2 - Agreement percentage (responses totally agree and partially agree) of enablers for establishing Nursing Care Systematization and the Nursing Process according to the perception of the nursing team - Campinas, SP, Brazil, 2015.

\section{Perception of the team on how the NCS and the NP ARE PERFORMED IN THE UNIT}

In this domain, professionals pointed out the frequency with which actions are performed in the unit according to their perception (Table 1). It was found that activities are not performed frequently.

\section{Perception of nURSes Regarding their INDIVIDUAL PERFORMANCE IN RELATION TO THE NP}

By analyzing the nurses' responses, it can be seen that the nursing process is still incipient in the unit, since the phases are not performed in a systematic way (Table 2). 
Table 1 - Percentage distribution of the answers to the questions about how Nursing Care Systematization and the Nursing Process in the unit are performed according to the perception of the nursing team - Campinas, SP, Brazil, 2015.

\begin{tabular}{|c|c|c|c|c|c|}
\hline & Never & Rarely & Sometimes & Often & Always \\
\hline Nursing consultations are performed using the NP & $10 \%$ & $24 \%$ & $38 \%$ & $24 \%$ & $5 \%$ \\
\hline The NCS is used in all nursing actions & $19 \%$ & $38 \%$ & $29 \%$ & $10 \%$ & $5 \%$ \\
\hline Nurses completely register the NP & $5 \%$ & $19 \%$ & $57 \%$ & $10 \%$ & $10 \%$ \\
\hline The nursing team values the NCS and checks the prescriptions & $14 \%$ & $29 \%$ & $43 \%$ & $10 \%$ & $5 \%$ \\
\hline The nursing team participates in the implementing of the NP & $19 \%$ & $33 \%$ & $29 \%$ & $19 \%$ & $0 \%$ \\
\hline The NP is carried out in accordance with COFEN standards & $14 \%$ & $24 \%$ & $38 \%$ & $24 \%$ & $0 \%$ \\
\hline The nurse has institutional support to perform the NCS/NP & $14 \%$ & $29 \%$ & $29 \%$ & $19 \%$ & $10 \%$ \\
\hline The unit has enough nurses & $24 \%$ & $24 \%$ & $0 \%$ & $24 \%$ & $29 \%$ \\
\hline $\begin{array}{l}\text { An inspection by the regulating organ (COREN) found } \\
\text { irregularities }\end{array}$ & $5 \%$ & $10 \%$ & $29 \%$ & $33 \%$ & $24 \%$ \\
\hline
\end{tabular}

Table 2 - Distribution of the answers to questions about nurses' perception of their individual professional performance in relation to the Nursing Process - Campinas, SP, Brazil, 2015.

\begin{tabular}{|c|c|c|c|c|c|}
\hline Question & Never & Rarely & Sometimes & Often & Always \\
\hline I perform data collection from nursing or nursing history & $0 \%$ & $25 \%$ & $50 \%$ & $25 \%$ & $0 \%$ \\
\hline I follow the nursing prescriptions and check the actions taken & $0 \%$ & $50 \%$ & $0 \%$ & $50 \%$ & $0 \%$ \\
\hline I evaluate the care provided & $0 \%$ & $50 \%$ & $25 \%$ & $25 \%$ & $0 \%$ \\
\hline I record all the steps I perform in the patient's chart & $0 \%$ & $50 \%$ & $25 \%$ & $25 \%$ & $0 \%$ \\
\hline I prescribe care for all patients & $0 \%$ & $25 \%$ & $75 \%$ & $0 \%$ & $0 \%$ \\
\hline I perform a nursing diagnosis & $0 \%$ & $25 \%$ & $50 \%$ & $25 \%$ & $0 \%$ \\
\hline I use nursing diagnoses based on the NANDA nomenclature & $50 \%$ & $25 \%$ & $25 \%$ & $0 \%$ & $0 \%$ \\
\hline I use diagnostics based on the ICNP nomenclature & $25 \%$ & $25 \%$ & $25 \%$ & $0 \%$ & $25 \%$ \\
\hline I use diagnostics based on the CIPESC nomenclature & $0 \%$ & $25 \%$ & $25 \%$ & $0 \%$ & $50 \%$ \\
\hline $\begin{array}{l}\text { I use a non-standardized nomenclature for performing nursing } \\
\text { diagnoses }\end{array}$ & $50 \%$ & $0 \%$ & $50 \%$ & $0 \%$ & $0 \%$ \\
\hline
\end{tabular}

Note: $\mathrm{N}=4$

\section{DISCUSSION}

The results demonstrate that the team has a reasonable understanding about the NCS and the NP, however it was verified that there are still doubts and conflicts of knowledge about the concepts. It is believed that the difficulty in relation to the concepts can be influenced by the lack of consensus in the literature itself, because sometimes the terms NCS and NP are treated as synonyms, but not in others ${ }^{(3)}$. The lack of knowledge about the conceptual aspects related to the NCS and the NP also appear in other studies ${ }^{(1,9)}$, which points out the need for further study on the subject.

Regarding training, the results showed that a portion of the participants in the study considered that their academic training and the technical and auxiliary courses do not prepare nursing practitioners for NSC practice. This is possibly due to the fact that there is still a gap between teaching and nursing professional practice ${ }^{(10)}$. It is necessary to review the curricula, because it is only possible to overcome the barriers to operationalizing the NCS through knowledge and integrating different nursing categories in compliance with legal requirements.

Given this situation, the nursing team points to permanent education as an enabler for implementing the NCS. In a study carried out in a hospitalization unit in Belo Horizonte, the participants also highlighted the need for permanent education for the effective implantation of the $\mathrm{NCS}^{(1)}$.

Regarding the barriers to implementing NCS, the result obtained in this study is similar to other studies that highlight some challenges for its effectiveness, such as: the great demand of users, which is larger than recommended for each team; little time for patient care; work overload; lack of permanent education; and a shortage of appropriate forms for this purpose ${ }^{(11)}$. In addition, authors cite the resistance to implementation, the lack of human resources and the dichotomy between the managerial and nursing care functions of the nurse ${ }^{(12)}$.

Notwithstanding the identified barriers, it was found that the majority of the nursing team agreed that the NCS and the NP could promote several benefits. For the patient, it provides safety and individualized care; in relation to the profession, the NCS favors nurse autonomy; and for the institution, it enables organizing team work and helps to achieve quality goals ${ }^{(13)}$. Therefore, the enablers pointed out by the team should be valued by the institution's management and by the municipality's nursing administration, since they can help the implementation of the NCS in the unit.

The results showed that the NCS and the NP are not part of the team's daily routine and that there is no established institutional process that enables homogeneous nursing practice. The use of such methodologies is therefore still incipient.

From nurses' responses regarding their individual performance, we can see that the NP is performed in an unsystematic or incomplete way. This result converges with another study that identified that NP is not performed in 
a systematic way, since the participants perform the NP phases independently, which may compromise quality and continuity of care ${ }^{(14)}$. There are authors who relate the non-use of the NCS by professionals to the gap between thinking and doing, because there is more concern with the quantitative attendance to the service demands than with the quality of care ${ }^{(11)}$.

Regarding the non-standardization of nomenclatures, we perceived that this difficulty is evident in the collective health area. In primary care, with the implementation of the current Health Information System for Primary Care (e-SUS/SISAB), there is a mandatory entry for all the multidisciplinary team professionals using the International Classification of Primary Care (ICPC-2). The International Classification of Primary Care (ICPC) is a problem classification system developed by the World Organization of Family Physicians (WONCA), whose objective is to catalog problems which are specific to Primary Health Care (PHC) and to offer nomenclatures which can be used by all health professions. According to COREN-SP 010/2015 ${ }^{(15)}$, it is up to nurses to use the ICPC classifications in their professional practice, which does not mean replacing the nursing diagnosis, but which should be complemented with the diagnostic classification systems used by nurses (NANDA-I, ICPC ${ }^{\circledast}$ or $\mathrm{CIPESC}^{\circledast}$ ).

\section{CONCLUSION}

The results of this study allow us to consider that the guiding objective of the research was achieved. Although the participants have pointed to the NCS and the NP as factors for improving care quality, they have not yet been implemented in their totality.
The study provides subsidies for effective implementation of the NCS and NP in the unit under study and can contribute to improving nursing practice. The findings indicate that there is a need for greater institutional engagement through developing training programs and specific protocols aiming to minimize barriers and to empower process facilitators.

The results obtained herein do not allow full generalization to other units, but may suggest ways to favor implementation of the NCS and the NP in services with similar contexts. Since implementation of this methodology is still a challenge in most institutions, recognizing barriers and enablers can be useful for developing strategies that aim to maximize implementation effectiveness.

Another point that deserves attention is the gap between the training and the practice of nursing professionals. It is necessary to review the teaching methodologies of the NCS and the NP in the academic course training of nursing professionals according to the required competence levels in both the undergraduate and in auxiliary and technical training courses. This is a critical step to articulate theory and practice in order to prepare the student for their professional life, aiming to not simply comply with a legal requirement, but rather a quality leap in nursing care.

It is necessary to emphasize the need for studies focused on primary care as a way to overcome the implementation barriers of the NCS and the NP at this healthcare level. Disseminating implementation experiences can aid in operationalizing and implementing NCS and NP in primary care.

\section{RESUMO}

Objetivo: Realizar um diagnóstico situacional da Sistematização da Assistência de Enfermagem em uma Unidade Básica de Saúde, na percepção da equipe de enfermagem. Método: Estudo quantitativo, descritivo-exploratório, realizado em uma Unidade Básica de Saúde no interior de São Paulo. Para a coleta de dados, utilizou-se de um questionário estruturado, contendo escala tipo Likert, previamente validado por especialistas. Resultados: O questionário foi aplicado a 21 profissionais de enfermagem. Verificou-se que a implantação da Sistematização da Assistência de Enfermagem e do processo de enfermagem ainda é incipiente nas Unidades Básicas de Saúde. Em relação ao seu uso em todas as ações de enfermagem: 19\% dos entrevistados acham que nunca é usada, 38\% acham que raramente e $29 \%$ responderam algumas vezes. As principais dificuldades apontadas foram relacionadas à falta de estrutura institucional, destacando-se a falta de capacitação por parte da instituição (81\%). A equipe possui entendimento razoável sobre o tema e apontou que a formação profissional não prepara para a realização da Sistematização da Assistência de Enfermagem na atenção primária. Conclusão: É necessário interesse institucional para a viabilização da implantação. $O$ estudo pode contribuir para a efetiva implantação nesta unidade e apontar diretrizes para a sua implementação em outros contextos similares.

\section{DESCRITORES}

Enfermagem de Atenção Primária; Processo de Enfermagem; Equipe de Enfermagem; Avaliação em Enfermagem.

\section{RESUMEN}

Objetivo: Llevar a cabo un diagnóstico situacional de la Sistematización de la Asistencia de Enfermería en una Unidad Básica de Salud, en la percepción del equipo enfermero. Método: Estudio cuantitativo, descriptivo exploratorio, realizado en una Unidad Básica de Salud en el interior São Paulo. Para la recolección de datos, se utilizó un cuestionario estructurado, conteniendo escala tipo Likert, previamente validado por expertos. Resultados: El cuestionario fue aplicado a 21 profesionales enfermeros. Se verificó que la implantación de la Sistematización de la Asistencia de Enfermería y del proceso de enfermería todavía es incipiente en las Unidades Básicas de Salud. Con respecto a su empleo en todas las acciones de enfermería: el 19\% de los entrevistados piensan que nunca se la utiliza, el 38\% piensan que rara vez y el $29 \%$ respondieron algunas veces. Las principales dificultades señaladas estuvieron relacionadas con la falta de estructura institucional, destacándose la falta de capacitación por parte del centro (81\%) El equipo tiene una comprensión razonable acerca del tema y señaló que la formación profesional no prepara para la realización de la Sistematización de la Asistencia de Enfermería en la atención primaria. Conclusión: Es necesario interés institucional para que sea factible la implantación. El estudio puede contribuir a la efectiva implantación en esta unidad y señalar directrices para su implantación en otros contextos similares.

\section{DESCRIPTORES}

Enfermería de Atención Primaria; Proceso de Enfermería; Grupo de Enfermería; Evaluación en Enfermería. 


\section{REFERENCES}

1. Oliveira CMD, Carvalho DV, Peixoto ERDM, Camelo LDV, Salviano MEM. Percepção da equipe de enfermagem sobre a implementação do processo de enfermagem em uma unidade de um hospital universitário. REME Rev Min Enferm [Internet]. 2012 [citado 2017 jun. 01]; 16(2):258-63. Disponível em: http://reme.org.br/artigo/detalhes/527

2. Conselho Federal de Enfermagem. Resolução COFEN n. 358, de 15 de outubro de 2009. Dispõe sobre a Sistematização da Assistência de Enfermagem (SAE) nas Instituições de Saúde Brasileiras [Internet]. Brasília: COFEN; 2009 [citado 2017 jun 01]. Disponível em: http:/l www.cofen.gov.br/resoluo-cofen-3582009_4384.html

3. Conselho Regional de Enfermagem de São Paulo. Processo de enfermagem: guia para a prática [Internet]. São Paulo: COREN-SP; 2015 [citado 2017 jun 01]. Disponível em: http://www.coren-sp.gov.br/sites/default/files/SAE-web.pdf

4. Santos WN, Santos AMS, Lopes TRPS, Araújo MZ, Rocha FCV. Sistematização da Assistência de Enfermagem: o contexto histórico, o processo e obstáculos da implantação. J Manag Prim Health Care. 2014;5(2):153-8.

5. Maroso KL, Adamy EK, Amora AR, Ferraz L, Lima TL, Neiss M. Sistematização da Assistência de Enfermagem na atenção básica: o que dizem os enfermeiros? Cienc Enferm [Internet]. 2015 [citado 2017 fev. 05]. Disponível em: http://www.redalyc.org/html/3704/370442674004/

6. Salvado PTCO, Santos VEP, Dantas CN. Caracterização das dissertações e teses brasileiras acerca da interface processo de enfermagem e atenção primária. REME Rev Min Enferm [Internet]. 2014 [citado 2017 fev. 05];18(2):295-309. Disponível em: http://www.reme.org.br/ artigo/detalhes/928

7. Cubas M, Albuquerque L, Martins S, Peruzzo S. Aplicação do Inventario Vocabular Resultante do Projeto CIPESC CIE-ABEn nas Unidades Básicas de Saúde do Município de Curitiba-PR. In: Egry EY, Garcia TR. Integralidade da atenção no SUS e Sistematização da assistência de Enfermagem. Porto Alegre: Artmed; 2010. p.318-23.

8. Hermida PMV, Araújo IEM. Sistematização da Assistência de Enfermagem: subsídios para implantação. Rev Bras Enferm [Internet]. 2006 [citado 2017 fev. 05];59(5):675-9. Disponível em: http://www.scielo.br/pdf/reben/v59n5/v59n5a15

9. Souza MFG, Santos ADB, Monteiro AI. O processo de enfermagem na concepção de profissionais de enfermagem de um hospital de ensino. Rev Bras Enferm [Internet]. 2013 [citado 2017 jul. 01];66(2):167-73. Disponível em: http://www.redalyc.org/html/2670/267028666003/

10. Grando T, Zuse CL. Dificuldades na implantação da Sistematização da Assistência de Enfermagem no exercício profissional: revisão integrativa. Rev Contexto Saúde [Internet] 2014 [citado 2017 jul. 01];14(26):28-35. Disponível em: https://www.revistas.unijui.edu.br/ index.php/contextoesaude/article/view/2886

11. Santana JCB, Rocha VAM, Oliveira E, Afonso LN, Santos SLR, Freitas VMF, et al. Percepção dos enfermeiros acerca da Sistematização da Assistência de Enfermagem na atenção básica de Belo Horizonte. Enferm Rev [Internet]. 2016 [citado 2017 jul. 01];16(1):4-17. Disponível em: http://periodicos.pucminas.br/index.php/enfermagemrevista/article/viewFile/12936/10175

12. Penedo RM, Spiri WC. Meaning of the Systematization of Nursing Care for nurse managers. Acta Paul Enferm [Internet]. 2014 [cited 2017 July 02];27(1):86-92. Available from: http://www.scielo.br/scielo.php?pid=S0103-21002014000100016\&script=sci_arttext

13. Medeiros AL, Santos SR, Cabral RWL. Sistematização da Assistência de Enfermagem na perspectiva dos enfermeiros: uma abordagem metodológica na teoria fundamentada. Rev Gaúcha Enferm [Internet] 2012 [citado 2017 jul. 05];33(3):174-81. http://www.seer.ufrgs.br/ RevistaGauchadeEnfermagem/article/viewFile/20492/21961

14. Martino MMF, Fogaça LF, Costa PCP, Toledo VP. Análise da aplicação do processo de enfermagem em um hospital governamental Rev Enferm UFPE On Line [Internet] 2014 [citado 2017 jul 05];8(5):1247-53. Disponível em: https://periodicos.ufpe.br/revistas/ revistaenfermagem/article/viewFile/9806/9975

15. Conselho Regional de Enfermagem de São Paulo. Parecer COREN-SP 010/2015-CT. Uso da Classificação Internacional da Atenção Primária (CIAP) por enfermeiros que atuam em Atenção Primária e Estratégia Saúde da Família [Internet]. São Paulo: COREN-SP; 2015 [citado 2017 jul 06]. Disponível em: http://portal.coren-sp.gov.br/sites/default/files/010.2015CIAP-2_Aprovada\%20na\%20ROP.pdf 